\title{
OSTATNIA DROGA SP. KS. PROF. PIOTRA STACHA
}

Dnia 19 czerwca 1961 r. po kilkudniowej chorobie zmarł na zawał serca w szpitalu w Nowym Sączu nestor biblistów polskich i współpracownik Ruchu Biblijnego i Liturgicznego oraz długoletni profesor Pisma św. Nowego Testamentu śp. ks. dr Piotr Stach.

Śmierć zaskoczyła go niemal w przede dniu jego złotego jubileuszu kapłańskiego, który miał obchodzić uroczyście 29 czerwca w swojej rodzinnej miejscowości w Ujanowicach pow. Limanowa. Sp. ks. prof. S t a c h doczeka się zapewne wkrótce obszernej swojej biografii, w której oceniona zostanie należycie jego wszechstronna działalność, zarówno naukowa, jak i dydaktyczna i pedagogiczna. Zanim jednak to nastąpi redakcja R. B. L. poczuwa się do obowiązku przynajmniej tym krótkim wspomnieniem uczcić pamięć znanego powszechnie i cenionego profesora.

Śp. ks. prof. Sta ch urodził się 14 sierpnia 1886 r. we wsi Ujanowice, pow. Limanowa, woj. Krakowskie. Studia gimnazjalne odbywał początkowo od r. 1899 w Nowym Sączu, a potem od 1903 r. w Tarnowie. W 1907 r. wstąpił do Seminarium Duchownego w Tarnowie, które ukończył w roku 1911. Dnia 29 czerwca 1911 r. wyświęcony na kapłana przez ówczesnego rządcę diecezji.JE. Ks. Bpa Leona Wałęgę, pełnił przejściowo obowiązki wikarego w Zassowie, by jeszcze w tym samym roku udać się na studia biblijne do Rzymu. W Rzymie studiuje na niedawno założonym przez św. Piusa X Papieskim Instytucie Biblijnym (założony w 1909 r.), który kończy w 1914 r. stopniem lektora Pisma św. W tym samym roku dla pogłębienia swoich studiów biblijnych odbywa dłuższa podróż do Ziemi Świętej, którą później jeszcze kilkakrotnie nawiedzi w swoim życiu.

Po powrocie do kraju na polecenie swoich władz duchownych oddaje się na krótko pracy duszpasterskiej, pełniąc kolejno obowiązki wikariusza w Trzcianie (k. Bochni), a potem przy kościele katedralnym w Tarnowie. W listopadzie 1917 r. otrzymuje doktorat z Teologii na UJ w Krakowie, a od 1919 r. zaczyna wykładać Pismo św. Nowego Testamentu na uniwersytecie Jana Kazimierza we Lwowie. W 1925 r. otrzymuje nominację na zwyczajnego profesora, po czym pełni czterokrotnie funkcję dziekana Wydz. Teol. Uniw. J. K., a w r. 1938/39 był prorektorem tegoż uniwersytetu. W 1927 r. odbył swoją drugą podróż naukową do Ziemi Swiętej oraz przebywał także w 1930 r. w celach naukowych w Lowanium i w Kartaginie. W 1934 r. otrzymał godność prałata domowego od J. Sw. papieża Piusa XI. W pierwszych latach okupacji wykładał Pisma św. w Zakładzie Teologicznym w Kalwarii, a potem w Seminarium Duchownym w Tarnowie. W r. 1950 powołano go na opróżnioną katedrę Nowego Testamentu na UJ w Krakowie, którą piastował ku wielkiemu zadowoleniu swoich słuchaczy aż do dnia przejścia w stan spoczynku tj. do $1953 \mathrm{r}$. Lata od 1953 do 1961, tj. do dnia swojej śmierci spędził niemal wy- 
łącznie w swojej rodzinnej miejscowości, korzystając z gościny tamtejszego proboszcza ks. dziekana Bernardyna Dziedziaka.

Pogrzeb śp. ks. Stach a odbył się 22 czerwca 1961 r. w Ujanowicach. Po uroczystej eksportacji, która miala miejsce 21. VI. wieczorem do kościoła parafialnego, na drugi dzień główną Mszę św. pontyfikalną odprawił ordynariusz tarnowski JE. Ks. Bp dr Karol Pękala, na której podniosłe kazanie wygłosił serdeczny kolega i przyjaciel zmarłego ks. prałat dr Aleksy Klawek. Dostojny mówca w pięknych i głębokich słowach nakreślił sylwetkę zmarłego, przedstawiając go słuchaczom jako dobrego człowieka, wnikliwego uczonego i szlachetnego, oddanego bożej sprawie kapłana. Szczególnie podkreślił ks. prał. Klaw e k zasługi zmarłego dla rozwoju ruchu biblijnego w Polsce oraz przypomniał jego troskę o rozpowszechnienie lektury Pisma św. wśród najszerszych rzesz społeczeństwa.

Po Mszy św. przemówił jeszcze od ołtarza JE. Ks. Bp P ękala, który między innymi przeczytał także list Ojca Swiętego Jana XXIII nadesłany do Zmarłego z okazji jego 50-lecia kapłaństwa. Kondukt żałobny poprowadził na cmentarz ordynariusz tarnowski w asyście księży biskupów: Michała Blecharczyka z Tarnowa, Wincentego Urbana z Wrocławia oraz Karola Wojtyły z Krakowa. Poza tym w pogrzebie wzięli udział przedstawiciele licznych kapitul, Katolickiego Uniwersytetu Lubelskiego z JM Ks. Rektorem Marianem Rechowiczem na czele oraz około 250 księży, głównie uczniów, przyjaciół i kolegów zmarłego. $\mathrm{Na}$ cmentarzu przemówił jeszcze ks. prof. Rechowicz, rektor KULu, który jako b. asystent śp. ks. Stacha wskazał na jego walory naukowe i osobiste, a szczególnie na jego serdeczny niemal ojcowski stosunek do studiującej młodzieży.

Śp. ks. prof. Stach prawie całe swoje życie poświęcił pracy naukowej, a szczególnie umiłowanej przez siebie dziedzinie Pisma św. Nowego Testamentu. $\mathrm{Z}$ tej też dziedziny zostawił po sobie ok. 80 mniejszych i większych rozpraw oraz ponad 100 różnych recenzji i sprawozdań z prac naukowych. Pod jego kierunkiem studenci UJ na Wydz. Teologicznym opracowali 14 szczegółowych komentarzy do ksiąg $\mathrm{N}$. Testamentu, z których kilka ukazało się drukiem jako prace doktorskie.

Z ważniejszych prac naukowych śp. ks. prof. Sta cha należy wymienić Nieomylność Chrystusa w kwestii eschatologicznej, Lwów 1920. Wypędzenie przekupniów z świątyni, Poznań 1923, Poselstwo Jana Chrzciciela do Chrystusa $w$ świetle historii egzegezy i krytyki biblijnej, Warszawa 1924, Księga Przyst. Ekkle, itp. w poznańskim wyd. Pisma św., Poznań 1927, Siw. Augustyn jako biblista, Lwów 1930. Podróż naukowa do Ziemi Świętej, Lwów 1936, Myśli społeczne w liście św. Jakuba, Kraków 1937, Sobór Trydencki a czytanie Pisma św., Kraków 1948, Miejsce zaśnięcia N. Marii Panny, Kraków 1950.

Po za tym śp. ks. prof. Sta ch po przejściu na emeryturę podjął się 
bardzo żmudnej pracy napisania historii dzialalności śp. bpa Leona Wałęgi, ordynariusza tarnowskiego w latach 1911-1933. Manuskrypt tej pracy ma dziś ponad 1000 stron maszynopisu i stanowi niezwykle cenny przyczynek do badań nad historią diecezji tarnowskiej.

Poza pracą naukową i dydaktyczną śp. ks. Stach rozwijał do ostatnich chwil swojego życia, na szeroką skalę zakrojoną, pracę pedagogiczną. Ukochałł młodzież, której służył zawsze radą, opieką i pomocą materialną i moralną. Z licznymi swoimi uczniami korespondował niemal do końca życia i cieszył się otrzymywanymi listami, na które odpisywał własnoręcznie. Śp. ks. prof. Stach pozostanie w naszej pamięci na zawsze jako nasz troskíiwy opiekun, doradca i dobroczyńca.

Kraków

Ks. STANISEAW GRZYBEK

\section{DNI GREGORIAŃSKIE ZAKONNIC}

W dniach 29-30 września 1960 odbyły się na Jasnej Górze Dni śpiewu gregoriańskiego zakonnic, które zgromadziły 500 sióstr z rozmaitych zakonów i zgromadzeń pod przewodnictwem pięciu Księży Biskupów. Dni rozpoczęły się 29 września Mszą pontyfikalną, którą celebrował J. E. Ks. Bp. Stanisław. Jakie1, Przewodniczący Podkomisji Muzyki Sakralnej przy Konferencji Episkopatu. Siostry odśpiewały IViszę IV i Credo I. Kazanie wygłosił O. B enignus, prowincjał OO Kapucynów. $\mathrm{Na}$ sali różańcowej Ks. Prof. Mi eczysław Jankowski odczytał list Jego Eminencji Ks. Prymasa, po czym powitali siostry: J. E. Ks. Bp Zdzisław Goliński, Ordynariusz częstochowski i O. Ludwik Nowak, generał OO. Paulinów. Następnie J. E. Ks. Bp Andrzej Wronka wygłosił referat pt. Msza św. centrum życia wewnętrznego, podkreślając związek ofiary życia zakonnego z ofiarą eucharystyczna. O. Benedykt Sczaniecki OSB mówił na temat Śpiew gregogiański $w$ życiu zakonnic. Po południu odśpiewano Nieszpory o Najświętszym Sakramencie, po czym S. Wiesława Zemla, Zgr. Rodziny Maryi, przeprowadziła lekcję pokazową ucząc uczestniczki ofertorium Ave Maria. Po lekcji S. Ida Plater, niepokalanka, wygłosiła referat Najpięknieisze pochwaty, o Najśw. Maryi Pannie, w którym podała historię i analizę hymnu Ave maris stella, sekwencji Stabat Mater i antyfony Salve Regina.

30 września J. E. Ks. Bp Goliński odprawił pontyfikalną Mszę wotywną o M. Bożej: Jasnogórskiej Fundamenta, wykonano Mszę IX i. Credo III, kazanie wygłosił J. E. Ks. Bp Jakie l. W pierwszym referacie Ks. Prof. Wojciech Lewkowicz zajął się zagadnieniami praktycznymi omawiając Drogi do urzeczywistnienia postulatów Stolicy świętej odnośnie śpiewu gregoriańskiego. Wskazał trzy drogi: kształcenie sióstr specjalistek, uczenie śpiewu w społecznościach zakonnych i pomoc 